\title{
1 Isolation of SAR11 marine bacteria from cryopreserved seawater
}

3 Elizabeth A. Monaghan ${ }^{a, b}$, Kelle C. Freel ${ }^{a}$, and Michael S. Rappéa\#

5 aHawai'i Institute of Marine Biology, School of Ocean and Earth Science and Technology,

6 University of Hawai'i at Mānoa, Kāne‘ohe, Hawai'i, USA

7 barine Biology Graduate Program, University of Hawai‘i at Mānoa, Honolulu, Hawai‘i, USA

9 Running Title: Isolation of SAR11 from cryopreserved seawater

11 \#Address correspondence to Michael S. Rappé, rappe@hawaii.edu

12 


\section{Abstract}

16 In this study, we sought a means to increase current culture collections of SAR11 marine bacteria

17 by testing the use of seawater cryopreserved with glycerol as an inoculum. In July 2017, raw

18 seawater was collected outside of Kāne'ohe Bay, Hawai'i, in the tropical Pacific Ocean. A

19 portion of this sample was diluted in seawater-based growth medium to create $576 \times 2 \mathrm{~mL}$

20 dilution cultures containing 5 cells each and incubated for a high-throughput cultivation

21 experiment, while another portion was cryopreserved in $10 \%$ glycerol. After ten months, a

22 cryopreserved aliquot of seawater was thawed, diluted in seawater-based growth medium, and

23 distributed to create a second high-throughput cultivation experiment of $480 \times 2 \mathrm{~mL}$ dilution

24 cultures containing 5 cells each and 94 cultures containing 105 cells each. The raw seawater

25 cultivation experiment resulted in the successful isolation of 54 monocultures and 29 mixed-

26 cultures, while cryopreserved seawater resulted in 59 monocultures and 29 mixed cultures.

27 Combined, the cultures included 51 SAR11 isolates spanning 11 unique 16S rRNA gene

28 amplicon sequence variants (ASVs) from raw seawater inoculum and 74 SAR11 isolates

29 spanning 13 unique ASVs from cryopreserved seawater. A vast majority (115 of 125) of SAR11

30 isolates from the two HTC experiments were members of SAR11 subclade Ia, though isolates of

31 subclades IIIa and Va were also recovered from cryopreserved seawater and subclade Ib was

32 recovered from both. The four most abundant SAR11 subclade Ia ASVs found in the initial

33 seawater sample used to create both culture experiments were isolated by both approaches.

35 Importance

36 High-throughput dilution culture has proved to be a successful approach to bring some difficult-

37 to-isolate planktonic microorganisms into culture, including the highly abundant SAR11 lineage 
38 of marine bacteria. While the long-term preservation of bacterial isolates by freezing in the

39 presence of cryoprotectants such as glycerol has been shown to be an effective method of storing

40 viable cells over long time periods (i.e. years), to our knowledge it had not previously been

41 tested for its efficacy in preserving raw seawater for later use as inoculum for high-throughput

42 cultivation experiments. We found that SAR11 and other abundant marine bacteria could be

43 isolated from seawater that was previously cryopreserved for nearly 10 months, at a rate of

44 culturability similar to that of the same seawater used fresh, immediately after collection. Our

45 findings expand the potential of high-throughput cultivation experiments to include opportunities

46 where immediate isolation experiments are impractical, allow for targeted isolation experiments

47 from specific samples based on analyses such as microbial community structure, and enable

48 cultivation experiments across a wide range of other conditions that would benefit from having

49 source inoculum available over extended periods of time. 


\section{Introduction}

The rapid advancement of molecular tools to investigate marine microorganisms in their

53 natural environment has led to unprecedented access to the genomic repertoire and transcription-

54 and protein-based assessments of activity within natural microbial cells, populations, and

55 communities $(1,2)$. It is currently feasible for a few liters of seawater to provide sequence data

56 that reveals microbial population structure, the identities of microbial community members, and

57 the presence and activity of potential metabolic functions they harbor (e.g. 3, 4). In recent years,

58 however, the value of having cultivated representatives of numerically abundant and

59 environmentally relevant microbial lineages has received renewed recognition (5-8). Access to

60 isolated strains or low-diversity enrichments of marine microorganisms that are commonly found

61 in the natural environment has provided a means to definitively test many hypotheses generated

62 from environmental observations and experiments, as well as whole genome sequences useful

63 for informing and guiding environmental genomics, transcriptomics, and proteomics research

64 (e.g. 5, 6). The importance of cultivating environmentally-relevant microorganisms from pelagic

65 marine ecosystems for laboratory-based experimentation is now generally appreciated. However,

66 evidence provided by the sequencing of environmental DNA continues to support the conclusion

67 that most of the microorganisms that appear to dominate pelagic marine ecosystems have not yet

68 been cultivated from seawater (11).

Several different isolation methods and strategies have been developed in order to coax

70 recalcitrant environmental microorganisms into laboratory culture (e.g 12-15). Among these

71 novel approaches is an isolation technique based on dilution-to-extinction culturing methodology

72 first developed by Button and colleagues (16). Although early dilution-to-extinction culturing

73 studies resulted in cultures of novel oligotrophs (16-18), the dilution culture strategy was not 
74 without limitations. For instance, the technique yielded only a small number of isolates, while

75 requiring a significant amount of time and effort per experiment. The high-throughput culturing

76 (HTC) approach is a variation of dilution-to-extinction culturing methodology tailored to

77 facilitate rapid, high-throughput experiments with high rates of replication and greater

78 opportunities to investigate physical, chemical, and biological variables $(19,20)$.

For over a decade since its initial discovery in 1990, the marine planktonic bacterial

80 lineage known as SAR11 served as a notorious example of an abundant and widespread

81 microorganism in nature that was recalcitrant to cultivation as an isolated strain in a controlled

82 laboratory setting $(21,22)$. The value of the HTC strategy was solidified when early trials

83 yielded the first cultured representatives of many marine microbial groups that were previously

84 known only from environmental SSU rRNA genes (19), including the first cultivated strains of

85 SAR11 (20). In general, the HTC approach employs growth media created from natural or

86 artificial seawater in order to dilute the cells within a fluid sample, which is then arrayed in high

87 density replicate cultures, propagated, and monitored under controlled conditions. In addition to

88 diverse SAR11 strains (20,23-28), the application of this method has resulted in the isolation of

89 numerous other important lineages of marine bacteria including OM43 (19, 29), SAR116 (23,

90 30), SAR92 (23, 31), and SUP05 (32), among others. While efforts have succeeded in isolating

91 many abundant planktonic marine bacteria, it remains that the genetic diversity harbored by these

92 lineages in nature greatly surpasses what has been isolated in the laboratory.

93 A current limitation of the HTC approach is that, thus far, it has only been used with

94 freshly collected inoculum. This presents a potential constraint on HTC experiments using fluid

95 samples collected in the field as it requires all of the resources necessary for setting up an HTC

96 experiment (appropriate laboratory space, biosafety cabinet, etc.) be available at or near the time 
97 and location of sampling. The preservation of cultivated bacterial strains by freezing in the

98 presence of cryoprotectants such as glycerol or dimethyl sulfoxide (DMSO) has proved an

99 effective method for preserving viable cells over long time periods (i.e. years), including

100 cultivated strains of SAR11 $(20,33,34)$. However, to our knowledge it has not previously been

101 tested for its efficacy in preserving raw seawater for subsequent use as inoculum for high-

102 throughput cultivation. In this study, we conducted HTC experiments to compare the use of a

103 raw seawater sample collected from the coast of $\mathrm{O}^{`} \mathrm{ahu}$, Hawai'i, in the tropical Pacific Ocean,

104 with a subsample of the same seawater that was cryogenically preserved for nearly ten months.

105 In particular, we sought to determine if members of the SAR11 lineage of marine bacteria could

106 be isolated from cryopreserved seawater and thus open the possibility to expand existing culture

107 collections of SAR11 to potentially include any locations where seawater samples could be

108 collected and preserved. 


\section{Results}

\section{Overview of HTC cultivation experiments}

112 Using seawater sampled outside of Kāne'ohe Bay on the island of O'ahu, Hawai'i (Fig.

113 1), two high-throughput cultivation experiments were conducted: one that used fresh seawater as

114 an inoculum, labeled HTC2017, and one that used a cryopreserved sample of the same seawater

$115 \sim 10$ months later (HTC2018) (Fig. 2). Of 576 initial $2 \mathrm{~mL}$ cultures inoculated with raw seawater

116 for the HTC2017 experiment, 150 exhibited positive growth after 56 days of incubation. Of

117 these, 123 contained sufficient volume of culture to be sub-cultured into $20 \mathrm{~mL}$ of fresh medium.

118 Following DNA extraction, sequencing, and the assignment of ASVs, 54 monocultures and 29

119 mixed cultures were recovered (Table 1). The remainder either did not yield an amplification

120 product or did not contain an $\mathrm{ASV} \geq 50 \%$ of the culture and thus were not considered further.

121 Fifty-four isolates were identified in the 29 mixed cultures (Table S1); the 108 unique isolates

122 identified in the HTC2017 experiment (monocultures plus isolates contained in mixed cultures)

123 were distributed amongst 28 ASVs in total (Table 2, Table S1). The HTC2017 experiment

124 yielded a culturability of $3.1 \%(2.5 \%-3.9 \%)$ when both monocultures and mixed cultures were

125 considered, and 2.0\% (1.5\% - 2.6\%) when considering only monocultures (Table 1$)$.

126 For the cryopreserved seawater experiment (HTC2018), wells were inoculated with either

1275 or 105 cells. Of the 480 initial $2 \mathrm{~mL}$ cultures inoculated with 5 cells well ${ }^{-1}$ of cryopreserved

128 seawater (HTC2018), 142 exhibited positive growth after 30 days of incubation. The 142

129 positive wells were subcultured into $20 \mathrm{~mL}$ seawater media and, after 72 days, 95 subcultures

130 ultimately exhibited growth. Following DNA extraction, sequencing, and the assignment of

131 ASVs, 39 monocultures and 11 mixed cultures were identified (Table 1). The remainder either

132 did not yield an amplification product or did not contain an ASV $\geq 50 \%$ of the culture and thus 
133 were not considered further. Sixteen isolates were identified in the 11 mixed cultures (Table S1).

134 Combined, the 55 unique isolates identified in the HTC2018 5 cells well-1 experiment were

135 distributed amongst 17 ASVs (Table 2, Table S1). The HTC2018 5 cells well ${ }^{-1}$ experiment

136 yielded a culturability of $2.2 \%(1.7 \%-2.9 \%)$ when both monocultures and mixed cultures were

137 considered, and $1.7 \%(1.2 \%-2.3 \%)$ when considering only monocultures (Table 1$)$.

138 Of the 470 initial $2 \mathrm{~mL}$ cultures inoculated with 105 cells well $^{-1}$ of cryopreserved

139 seawater (HTC2018), 343 exhibited positive growth after 31 days of incubation. A single 96-

140 well cultivation plate containing 64 positive wells and two uninoculated control wells were

141 selected for further processing. Following DNA extraction, sequencing, and the assignment of

142 ASVs, 20 monocultures and 18 mixed cultures were identified (Table 1). The remainder either

143 did not yield an amplification product or did not contain an ASV $\geq 50 \%$ of the culture and thus

144 were not considered further. Thirty-five isolates were identified in the 18 mixed cultures (Table

$145 \mathrm{~S} 1)$; combined, the 55 unique isolates identified in the 105 cells well ${ }^{-1}$ HTC2 018 experiment

146 were distributed amongst 21 ASVs (Table 2, Table S1). The HTC2018 105 cells well $^{-1}$

147 experiment yielded a culturability of $0.5 \%(0.3 \%-0.7 \%)$ when both monocultures and mixed

148 cultures were considered, and $0.2 \%(0.1 \%-0.4 \%)$ when considering only monocultures (Table

149 1).

151 Identity of isolates

152 After quality control, each culture was sequenced to an average depth of $14,047 \pm 8,014$

153 (s.d.; range of 679 - 57,557) reads. Regardless of whether they originated from raw or

154 cryopreserved seawater, the broad, bacterial family-level taxonomic identity of isolates revealed

155 substantial overlap between culture experiments (Table 2, Table S1). Members of the 
156 alphaproteobacterial SAR11 subclade I, the marine gammaproteobacterial family Halieaceae,

157 and the alphaproteobacterial family Rhodobacteraceae were the first-, second-, and third-most

158 abundant families isolated in both the fresh seawater (HTC2017) and cryopreserved seawater

159 (HTC2018) cultivation experiments (Table 2, Table S1). Combined, these three groups made up

$16082 \%$ (89 of 108) and 88\% (97 of 110) of isolates recovered from HTC2017 and HTC2018,

161 respectively. Other bacterial families with isolates shared between HTC2017 and HTC2018

162 include the PS1 clade of Alphaproteobacteria and Burkholderiaceae within the

163 Betaproteobacteria (Table 2, Table S1). When the five bacterial families shared between

164 HTC2017 and HTC2018 are considered, the fresh seawater and cryopreserved seawater

165 cultivation experiments shared 89\% (96 of 108) and 93\% (102 of 110) of isolated strains,

166 respectively.

SAR11. A total of 51 strains representing 11 unique ASVs of SAR11 marine bacteria

168 (alphaproteobacterial order Pelagibacterales) were cultivated in HTC2017, while 74 strains

169 representing 13 ASVs were cultivated in HTC2018 (Fig. 3, Table 2, Table S1). They make up

$17047 \%$ and $67 \%$ of the isolates recovered in the two experiments, respectively. The vast majority of

171 these isolates were members of SAR11 subclade Ia, including 47 strains from HTC2017 and 68

172 strains from HTC2018. Each experiment resulted in the isolation of nine subclade Ia ASVs,

173 including five that were common between the two experiments (Figs. 3 \& 4, Table S1). The two

174 most often isolated SAR11 subclade Ia ASVs were shared between the two experiments:

175 ASV003 (25 and 37 isolates) and ASV002 (11 and 13 isolates) from HTC2017 and HTC2018,

176 respectively (Fig. 3, Table S1). Two other subclade Ia ASVs (ASV034 and ASV046) consisted

177 of multiple strains from both experiments, while 7 subclade Ia ASVs consisted of a single isolate

178 from one experiment (Fig. 3, Table S1). 
Strains affiliated with SAR11 subclade $\mathrm{Ib}$ were also isolated from both fresh and cryopreserved seawater, including 4 isolates across 2 ASVs from HTC2017 and 3 isolates across

1812 ASVs from HTC2018 (Fig. 4, Table S1). SAR11 subclade Ib ASV060 consisted of 3 and 2

182 isolates from HTC2017 and HTC2018, respectively, while each experiment also yielded an

183 isolate with a unique subclade Ib ASV (Fig. 3, Table S1). Two SAR11 subclades were only

184 isolated from the cryopreserved seawater sample, including two isolates from subclade IIIa 185 (ASV188) and one isolated from subclade Va (ASV200) (Fig. 3, Table 2, Table S1).

OM60(NOR5). Within the gammaproteobacterial family Halieaceae, the marine OM60(NOR5) clade made up 24 and 21 isolates, or 22\% and 19\% of HTC2017 and HTC2018,

188 respectively (Table 2). The 4 ASVs that accounted for the 24 isolates from HTC2017 were 189 shared with HTC2018, where they accounted for 19 of the 21 isolates recovered from that 190 experiment (Fig. 5, Table S1). One additional OM60(NOR5) ASV (ASV201) consisting of 2

191 isolates was recovered from cryopreserved seawater (Fig. 5, Table S1). Two closely related 192 ASVs (ASV032 and ASV018) accounted for most of the OM60(NOR5) strains isolated from 193 both experiments of this study (Fig. 5, Table S1). ASV32 was identical to strain HIMB55, a 194 genome-sequenced member of the OM60(NOR5) clade previously isolated from Kāne'ohe Bay, 195 Hawai'i (35).

Rhodobacteraceae. The marine alphaproteobacterial family Rhodobacteraceae made up

19714 and 5 isolates, or 13\% and 5\% of HTC2017 and HTC2018, respectively (Table 2). The strains 198 were distributed amongst 4 (HTC2017) and 5 (HTC2018) ASVs, including three (ASV12, 199 ASV71, ASV124) that were shared between the two experiments (Fig. 5, Table S1). Eight of 14 200 Rhodobacteraceae isolates recovered from HTC2107 belonged to a single ASV (ASV012). 
201 ASV71 was identical to strain HIMB11, a genome-sequenced member of the Rhodobacteraceae 202 previously isolated from Kāne'ohe Bay, Hawai'i (Fig. 5) (36).

Other isolates. In addition to the SAR11, OM60(NOR5), and Rhodobacteraceae ASVs

204 described above, one additional ASV was isolated in both experiments: ASV190 within the

205 betaproteobacterial family Burkholderiaceae was represented by 4 strains in HTC2017 and 1 in

206 HTC2018 (Table S1). While identical ASVs were not isolated, members of the marine

207 alphaproteobacterial PS1 clade within the order Parvibaculales were recovered from both

208 cultivation experiments, including 3 isolates from a single ASV (ASV137) in HTC2017 and 4

209 isolates from 3 ASVs in HTC2018 (Fig. 5, Table S1). The remaining ASVs were recovered as

210 either singletons or pairs of strains except for the OM43 clade of the Betaproteobacteriales,

211 which constituted five strains across 2 ASVs from the fresh seawater inoculum (HTC2017) only

212 (Table S1).

213

214 Comparisons with inoculum microbial community

215 After quality control, the 16S rRNA gene amplicon from the inoculum seawater sample

216 was sequenced to a depth of 65,924 reads. This sample harbored a microbial community

217 dominated by typical marine bacteria, including the marine picocyanobacteria Prochlorococcus

218 and Synechococcus, multiple subclades of the SAR11 lineage, the family Flavobacteriaceae of

219 the bacterial phylum Bacteroidetes, diverse members of the gammaproteobacterial SAR86 and

220 OM60(NOR5) lineages and alphaproteobacterial SAR116 and Rhodobacteraceae lineages, and

221 Actinomarinaceae of the bacterial phylum Actinobacteria, among others (Table S1).

Within the inoculum sample, 53 SAR11 ASVs totaling $26 \%$ of the microbial community

223 were identified. These spanned a diverse array of subclades that included Ia, Ib, IIa, IIIa, IV, Va, 
and $\mathrm{Vb}$ (Fig. 3, Table S1). Eight of the 53 SAR11 ASVs were isolated from at least one individual ASVs in the inoculum seawater community (Table S1). A fifth was cultivated in HTC2017 only (Fig. 3, Table S1). Eight SAR11 subclade Ia ASVs were isolated that did not

231 appear in the inoculum seawater community (Figs. 3 \& 4, Table S1).

234 subclade Ib ASVs that appeared in the inoculum was isolated (ASV060; Fig. 3, Table S1),

235 although it was cultivated in both HTC2017 and HTC2018 experiments. From the HTC2018

236 experiment, one of four subclade IIIa ASVs (ASV188) was isolated, as well as one of two

237 subclade Va ASVs (ASV200; Fig. 3, Table S1). Thirteen Rhodobacteraceae ASVs were

238 identified in the environmental sample, of which the same three (ASV012, ASV071, ASV124)

239 were cultivated from both fresh and cryopreserved seawater (Fig. 5, Table S1). Four of the five

240 total most environmentally abundant OM60(NOR5) clade ASVs were also cultivated in both

241 experiments (Table S1). Despite 19 ASVs appearing in the inoculum, only one SAR116 ASV

242 (ASV142; Fig. 5, Table S1) was cultivated in the HTC2017 experiment.

Mixed cultures 
247 contained ASVs from either SAR11 subclade Ia or the OM60(NOR5) clade, which is logical

248 given the high recovery of monocultures from these two groups in both cultivation experiments

249 (Fig. S1). Of nine mixed cultures containing OM60(NOR5) ASV018, eight also contained

250 SAR11 subclade Ia ASV002, ASV003, or ASV034 (Fig. S1, Table S1). Eight of the 11 mixed

251 cultures containing OM60(NOR5) ASV032 also contained a SAR11 subclade Ia ASV as well

252 (Fig. S1, Table S1). All cultivated OM43 clade ASVs were in mixed cultures; both of the OM43

253 clade ASV202 isolates appeared in co-culture with the OM43 clade ASV195 (Fig. S1, Table S1). 


\section{Discussion}

For a variety of reasons, SAR11 marine bacteria remain a target for culturing

257 experiments, despite being first isolated nearly 20 years ago (20). In large part, this is driven by

258 the enormous genomic diversity harbored by this lineage and the probability for ecotypic

259 differentiation across the SAR11 phylogenetic tree $(3,26,37,38)$. Living cultures offer a direct

260 means to characterize and quantify the cellular and physiological features that underly

261 differences in abundance or activity observed via direct environmental sampling $(4,39,40)$. The

262 primary goal of this study was to test the hypothesis that SAR11 marine bacteria can be isolated

263 from cryogenically preserved seawater. We reasoned that, since existing SAR11 isolates could

264 be cryopreserved in the presence of $10 \%$ glycerol (e.g. 20, 33, 34), then there was no a priori

265 reason to believe that natural populations of SAR11 cells could not similarly be preserved. One

266 of many unknown variables, however, was whether or not the process of cryopreservation would

267 result in significant cell loss and thus affect cultivation efficiency. At an equivalent-sized

268 inoculum of five cells, we found that not only were SAR11 strains able to be cultivated from

269 cryopreserved seawater, but the overall culturability was similar between the fresh and

270 cryopreserved seawater samples. Both experiments resulted in the isolation of representatives

271 from the four most abundant SAR11 subclade Ia ASVs in the original inoculum seawater

272 sample, as well as strains from subclade Ib. The cryopreserved seawater sample also proved

273 capable of serving as an inoculum to isolate other SAR11 subclades, as evidenced by the

274 recovery of isolates from within subclade IIIa (two strains) and Va (one strain) from the

275 cryopreserved sample only.

276 In addition to numerous isolates from SAR11 subclade Ia that appear to represent

277 abundant ASVs in the seawater sample used as inoculum for these experiments, this study 
278 yielded seven strains of SAR11 subclade Ib in either mono- or mixed-culture. Despite being a

279 widespread and frequently abundant lineage of SAR11 in the global surface ocean (41-43), only

280 one cultivated representative of subclade Ib had been previously reported, from the Red Sea (28).

281 In addition to the novel isolates of subclade Ib, two strains of subclade IIIa and one of Va were

282 isolated from cryopreserved seawater indicating that a broad range of SAR11 diversity covering

283 at least four major sublineages can be cultivated by this approach, with no apparent negative

284 affect from the cryopreservation treatment itself.

285 As demonstrated by their recovery here, a range of other oligotrophic marine bacteria can

286 be isolated from cryopreserved seawater coupled with an HTC approach. This includes

287 representatives from the OM60(NOR5) clade, a ubiquitous lineage of oligotrophic marine

288 Gammaproteobacteria (OMG) that has been consistently isolated via HTC approaches (e.g. 19,

289 27, 31), including from coastal Hawai'i (35). The OM60(NOR5) lineage was the second most-

290 commonly isolated group of marine bacteria, behind only SAR11 subclade Ia, whether using

291 fresh or cryopreserved seawater as inoculum. Of five OM60(NOR5) ASVs present in the

292 seawater used as inoculum, the four most abundant were isolated in both cultivation experiments,

293 indicating no apparent effect of using cryopreserved seawater as an inoculum for isolating

294 members of the OM60(NOR5) lineage. A similar pattern emerged for the Rhodobacteraceae

295 lineage of marine Alphaproteobacteria, where isolates from the same three ASVs were

296 recovered in each of the two cultivation experiments, out of 13 total Rhodobacteraceae ASVs

297 identified in the environmental sample. This included the most abundant Rhodobacteraceae ASV

298 from the seawater inoculum, as well as an ASV identical to the previously isolated and genome-

299 sequenced strain HIMB11 from the same sampling location (36). We found only one abundant

300 (>3) set of strains that was isolated by using raw seawater as inoculum without corresponding 
301 strains also isolated using cryopreserved seawater: five strains belonging to two ASVs within the

302 OM43 clade of Betaproteobacteria were isolated in mixed- and mono-cultures. While this may

303 indicate that the cryopreservation process had a negative impact on the viability of OM43 clade

304 cells, we note that previously isolated members of this lineage have been successfully

305 cryopreserved in an identical fashion to the method employed in the current study $(29,44)$. Thus,

306 there is also the potential that this difference stems from stochasticity related to diluting the two

307 inocula nearly one million-fold.

308 Combining a barcoded next-generation 16S rRNA gene amplicon sequencing approach

309 with a high-throughput dilution culture strategy proved to be a rapid and sensitive means with

310 which to identify strains and assess the constituent taxa within mixed cultures. By barcoding and

311 sequencing each individual culture in the same manner as if it were a mixed microbial

312 community, we obtained taxonomic and proportional data on the microorganisms growing within

31358 mixed cultures of up to four constituent ASVs. Recent studies have highlighted the intricacies

314 that interweave the metabolisms of microorganisms inhabiting seawater (e.g. 4, 45); in natural

315 systems, it is probable that a portion of marine microorganisms require as-yet-unidentified

316 growth factors from co-existing cells $(46,47)$. These dependencies can be identified and

317 investigated by combining a miniaturized, high-throughput approach to cultivate and screen 100 s

318 to 1000 s of dilution cultures with an inoculum size aimed at growing mixed consortia and a rapid

319 sequence-based screening method that is appropriate for mixed communities, like the one used

320 here.

321 Consistent with recent observations (27), this set of experiments resulted in the isolation

322 of several bacterioplankton lineages that have been isolated numerous times via HTC and thus

323 appear readily amenable to cultivation via this approach, including members of SAR11 subclade 
324 Ia, the OM60(NOR5) lineage, and the Rhodobacteraceae. However, it remains that a large

325 portion of the diversity of marine microbes is still being missed in contemporary cultivation

326 efforts. For example, when considering only the putatively heterotrophic, non-cyanobacterial

327 fraction of the microbial community targeted in this study, major lineages including the

328 Flavobacteriaceae, SAR86 clade, Marinimicrobia (SAR406 clade), and marine Actinobacteria

329 (Candidatus Actinomarina) were missed completely. At the single-nucleotide resolution of

330 ASVs, abundant lineages of SAR116 and SAR11 subclades Ib, IIa, and Vb were also

331 conspicuously missed. While this study does not offer a panacea for isolating any of these well-

332 known but as-yet-uncultivated (or undercultivated) lineages in laboratory culture, it presents a

333 method by which high-throughput isolation experiments can be repeatedly performed on an

334 identical set of cryopreserved seawater samples such that requirements for growth can be

335 systematically tested in a cumulative fashion.

In summary, we have demonstrated that a broad range of marine bacterioplankton taxa

337 can be isolated from glycerol-cryopreserved seawater via an HTC approach, and that the

338 cryopreservation process itself did not negatively affect culturability or influence the taxonomic

339 identify of the resulting isolates. Strains of SAR11 subclades Ia, Ib, IIIa, and Va are amenable to

340 isolation from cryopreserved seawater, as well as other abundant lineages of marine bacteria

341 such as OM60(NOR5), oligotrophic Rhodobacteraceae, and the PS1 clade. This study

342 demonstrates that cryopreserved seawater can be used as a means to expand the breadth of HTC

343 studies to anywhere cryopreserved stocks can be made, and opens new opportunities to

344 repeatedly interrogate individual water samples or selectively target specific samples for

345 cultivation once ancillary data is in hand. 


\section{Materials and Methods}

\section{Processing of seawater for growth experiments}

On 26 July 2017, a 4 L seawater sample was collected in an acid washed polycarbonate

350 (PC) bottle from a depth of $2 \mathrm{~m}$ at station STO1 (N $\left.21^{\circ} 28.974^{\prime}, \mathrm{W} 157^{\circ} 45.978^{\prime}\right)$ outside of

351 Kāne‘ohe Bay, O`ahu, Hawai'i (Fig. 1). Within 1 hr of collection, subsamples of the raw

352 seawater were used to enumerate planktonic microorganisms, cryopreserve subsamples, collect

353 microbial biomass for environmental DNA, and serve as inoculum for a high-throughput

354 cultivation experiment (Fig. 2). Microbial cells were enumerated by staining with SYBR Green I

355 nucleic acid stain (Invitrogen, Carlsbad, CA, USA) and counted on a Guava easyCyte 5HT flow

356 cytometer (Millipore, Burlington, MA, USA) following a previously published protocol (48). To

357 cryopreserve the raw seawater, individual $1.5 \mathrm{~mL}$ subsamples were added to $375 \mu \mathrm{L}$ of $50 \%$

358 glycerol solution (v/v in sterile Kāne'ohe Bay seawater; 10\% final concentration) in $2 \mathrm{~mL}$

359 cryovials (Nalgene, Rochester, NY, USA) at room temperature $\left(24^{\circ} \mathrm{C}\right)$, mixed by inverting, and

360 cooled at a rate of $-1^{\circ} \mathrm{C} \min ^{-1}$ with a Cryo $1^{\circ} \mathrm{C}$ Freezing Container (Nalgene) inside a $-80^{\circ} \mathrm{C}$

361 ultracold freezer. Approximately 1.3 L of the raw seawater sample was collected on a $25 \mathrm{~mm}$

362 diameter, $0.1 \mu \mathrm{m}$ pore-sized polyethersulfone membrane (Supor-100; Pall Gelman Inc., Ann

363 Arbor, MI). The filter was submerged in $500 \mu \mathrm{L}$ DNA lysis buffer $(49,50)$ and stored at $-80^{\circ} \mathrm{C}$

364 until DNA extraction.

365

366 High-throughput cultivation experiment with raw seawater 
370 Hawai'i (Fig. 1), in acid-washed 4-L PC bottles. Within 1 hr of collection, the seawater was

371 sequentially filtered through pre-rinsed (10 L sterile water followed by $10 \mathrm{~L}$ seawater) $0.8-, 0.2-$,

372 and $0.1-\mu \mathrm{m}$ pore-sized polyethersulfone (PES) membranes (AcroPak 20 and Supor 100; Pall

373 Corp., Port Washington, NY, USA) into clean 4-L PC bottles. Bottles were then autoclaved for 3

374 hours (h) at $121^{\circ} \mathrm{C}$ and allowed to cool. The sterile seawater was sparged with $\mathrm{CO}_{2}$, followed by

375 air, through three in-line HEPA vent filters $(0.3-\mu \mathrm{m}$ glass-fiber to $0.2-\mu \mathrm{m}$ PTFE to $0.1-\mu \mathrm{m}$

376 PTFE; Whatman, GE Healthcare Life Sciences, Chicago, IL, USA) and stored at $4^{\circ} \mathrm{C}$ until use.

377 The $\mathrm{pH}$ of the seawater was checked prior to autoclaving and after sparging to ensure continuity

378 of the inorganic carbon chemistry.

Subsamples of raw seawater were diluted in the sterile seawater to 2.5 cells $\mathrm{mL}^{-1}$ and

380 arrayed in $2 \mathrm{~mL}$ volumes (5-cell inoculum) into 576 wells of custom fabricated 96-well Teflon

381 microtiter plates. Plates were sealed with breathable polypropylene microplate adhesive film

382 (VWR, Radnor, PA, USA) and incubated at $27^{\circ} \mathrm{C}$ in the dark. The presence of cellular growth

383 was monitored at 3.5 and 8 weeks via flow cytometry (Tripp et al. 2008). This experiment is

384 hereafter referred to as HTC2017.

Wells that exhibited positive growth of $>10^{4}$ cells $\mathrm{mL}^{-1}$ were sub-cultured by transferring

$3861 \mathrm{~mL}$ into $20 \mathrm{~mL}$ of sterile seawater media amended with $400 \mu \mathrm{M}\left(\mathrm{NH}_{4}\right)_{2} \mathrm{SO}_{4}, 400 \mu \mathrm{M} \mathrm{NH} \mathrm{Nl}_{4}$,

$38750 \mu \mathrm{M} \mathrm{NaH}_{2} \mathrm{PO}_{4}, 1 \mu \mathrm{M}$ glycine, $1 \mu \mathrm{M}$ methionine, $50 \mu \mathrm{M}$ pyruvate, $800 \mathrm{nM}$ niacin (B3), 425

$388 \mathrm{nM}$ pantothenic acid (B5), $500 \mathrm{nM}$ pyridoxine (B6), $4 \mathrm{nM}$ biotin (B7), $4 \mathrm{nM}$ folic acid (B9), 6

$389 \mu \mathrm{M}$ myo-inositol, $60 \mathrm{nM}$ 4-aminobenzoic acid, and $6 \mu \mathrm{M}$ thiamine hydrochloride (B1).

390 Subcultures were subsequently incubated at $27^{\circ} \mathrm{C}$ in the dark and monitored for growth after 4.5

391 weeks. Those that again reached $>10^{-4}$ cells $\mathrm{mL}^{-1}$ were cryopreserved $(500 \mu \mathrm{L}$ of culture with

$39210 \% \mathrm{v} / \mathrm{v}$ glycerol, final concentration) in the same manner as described for raw seawater. Cells in 
393 the remaining volume of culture $(\sim 18 \mathrm{~mL})$ were collected by filtration through $13 \mathrm{~mm}$ diameter,

$3940.03 \mu \mathrm{m}$ pore-sized PES membrane filters (Sterlitech, Kent, WA, USA), submerged in $250 \mu \mathrm{L}$

395 DNA lysis buffer, and stored at $-80^{\circ} \mathrm{C}$ until DNA extraction.

High-throughput cultivation experiment with cryopreserved seawater

After 42 weeks of storage at $-80^{\circ} \mathrm{C}$, one cryopreserved stock of raw seawater from station

399 STO1 was thawed to room temperature $\left(\sim 24^{\circ} \mathrm{C}\right)$, diluted ten-fold in sterile seawater growth

400 medium, and enumerated via staining with SYBR Green I and flow cytometry. The

401 cryopreserved sample was subsequently diluted with nutrient-amended sterile seawater growth

402 medium to two different concentrations: 2.5 and 52.5 cells $\mathrm{mL}^{-1}$. The 2.5 cells $\mathrm{mL}^{-1}$ dilution was

403 used to create 480 2-mL dilution cultures (5-cell inoculum) in custom fabricated 96-well Teflon

404 microtiter plates, while the 52.5 cells $\mathrm{mL}^{-1}$ dilution was used to create 4702 -mL dilution cultures

405 (105-cell inoculum). Ten control wells containing uninoculated sterile seawater growth medium

406 were also included. Teflon plates were sealed with breathable polypropylene microplate adhesive

407 film (VWR) and incubated at $27^{\circ} \mathrm{C}$ in the dark. Growth was monitored at 2, 3, and 5 weeks post-

408 inoculation as described above. Dilution cultures from the 5-cell inoculum showing positive

409 growth $\left(>10^{4}\right.$ cells $\left.\mathrm{mL}^{-1}\right)$ after 5 weeks of incubation were subcultured by distributing $1 \mathrm{~mL}$ of

410 initial culture into $20 \mathrm{~mL}$ of sterile seawater growth medium, and monitored for growth during

411 incubation for up to 10 weeks at $27^{\circ} \mathrm{C}$ in the dark. This experiment is hereafter referred to as

412 HTC2018.

413 Subcultures from the 5-cell cryopreserved seawater inoculum that reached $>10^{-4}$ cells

$414 \mathrm{~mL}^{-1}$ were cryopreserved $(500 \mu \mathrm{L}$ of culture with $10 \% \mathrm{v} / \mathrm{v}$ glycerol, final concentration) as

415 described above. Cells in the remaining volume $(\sim 18 \mathrm{~mL})$ were collected by filtration through 
$4160.03 \mu \mathrm{m}$ pore-sized PES membrane filters (Sterlitech), submerged in $250 \mu \mathrm{L}$ DNA lysis buffer,

417 and subsequently stored at $-80^{\circ} \mathrm{C}$ until DNA extraction.

418 The 105-cell inoculum was not subcultured. Instead, wells from one 96-well microtiter

419 plate that exhibited growth $\left(>10^{-4}\right.$ cells $\left.\mathrm{mL}^{-1}\right)$ were cryopreserved by combining glycerol solution

420 to a final concentration of $10 \% \mathrm{v} / \mathrm{v}$ in $250 \mu \mathrm{L}$ of subculture and frozen as above. Cells in the

421 remaining volume of subculture $(\sim 1 \mathrm{~mL})$ were collected by filtration through $0.03 \mu \mathrm{m}$ pore-sized

422 PES membrane filters (Sterlitech), submerged in $250 \mu \mathrm{L}$ DNA lysis buffer, and subsequently

423 stored at $-80^{\circ} \mathrm{C}$ until DNA extraction.

\section{DNA extraction and sequencing}

Genomic DNA was extracted from the environmental sample and all 5-cell subcultures

427 that exhibited growth using the Qiagen DNeasy Blood \& Tissue Kit following the

428 manufacturer's instructions for bacterial cells (Qiagen, Germantown, Maryland, USA). Genomic

429 DNA was extracted from one 96-well microtiter plate of the 105-cell cryopreserved seawater

430 inoculum cultures that exhibited growth using the DNEasy 96 Blood \& Tissue Kit (Qiagen) in

431 accordance with the manufacturer's protocol. Genomic DNA from the environmental sample and

432 all 5-cell subcultures was used as template for polymerase chain reaction (PCR) amplification

433 (Bio Rad C1000 Touch, Bio Rad, Hercules, CA, USA) using barcoded 515F and 926R primers

434 targeting the V4 region of the SSU rRNA gene (52) in a total reaction volume of $25 \mu \mathrm{L}$

435 containing $2 \mu \mathrm{L}$ of genomic DNA template, $0.5 \mu \mathrm{L}$ each forward and reverse primer, $10 \mu \mathrm{L}$

436 5PRIME HotMasterMix (Quantabio, Beverly, MA, USA), and $12 \mu \mathrm{L}$ of $\mathrm{H}_{2} \mathrm{O}$. The reaction

437 included an initial denaturing step of $3 \mathrm{~min}$ at $94^{\circ} \mathrm{C}$ followed by 40 cycles of $45 \mathrm{sec}$ at $94^{\circ} \mathrm{C}, 1$

$438 \mathrm{~min}$ at $50^{\circ} \mathrm{C}$ and $1.5 \mathrm{~min}$ at $72^{\circ} \mathrm{C}$, and a final extension of $10 \mathrm{~min}$ at $72^{\circ} \mathrm{C}$. 
A nested-PCR approach was used to amplify SSU rRNA gene fragments from genomic

440 DNA recovered from the 105-cell inoculum cryopreserved seawater cultures. The first reaction

441 employed bacterial 27FB (53) and 1492R (54) primers in a $25 \mu \mathrm{L}$ total reaction volume as

442 described above. The reaction included an initial denaturing step of $3 \mathrm{~min}$ at $94^{\circ} \mathrm{C}$ followed by 35

443 cycles of $30 \mathrm{sec}$ at $94^{\circ} \mathrm{C}, 1 \mathrm{~min}$ at $50^{\circ} \mathrm{C}$ and $45 \mathrm{sec}$ at $72^{\circ} \mathrm{C}$, and a final extension of $18 \mathrm{~min}$ at

$44472^{\circ} \mathrm{C}$. PCR products from the first amplification were then used as template for a second

445 amplification reaction using the barcoded 515F and $926 \mathrm{R}$ primers (52), using the same reaction

446 conditions as described for the 5-cell inoculum samples.

All PCR products were quantified (Qubit 2.0, Invitrogen), pooled at a concentration of 240 ng sample ${ }^{-1}$, and cleaned (QIAquick PCR Purification Kit, Qiagen). Pooled products were 449 sequenced via three Illumina MiSeq 250 bp paired-end runs using v.2 reagent kits.

\section{Sequence analysis}

The three Illumina MiSeq runs were each separately imported into QIIME2 v2019.4.0,

453 demultiplexed, and paired ends were analyzed for sequence quality and merged (55). The

454 DADA2 software package (56) was then used to denoise sequences, including removal of

455 chimeras. Due to the low quality at the end of the sequences, 10 bases were truncated from the 3'

456 end of the reverse reads. Sequence reads from the three runs were then merged post-denoising.

457 Amplicon sequence variant (ASV) identities were defined by DADA2 for all reads that varied by

458 at least one base pair. Taxonomy was assigned to each ASV using a Naïve Bayes classifier

459 trained on the Silva rRNA v132 database (57) clustered at 99\% similarity and subsequently

460 modified manually based on phylogenetic analyses and the results of previous work. Denoised

461 sequences, ASVs, and taxonomy classifications were imported into R v3.5 (58) using the 
462 phyloseq v1.26.1 package (59) for additional manual curation as outlined below. Visualizations

463 were created in R using ggplot2 (60) and in BioVenn (61).

The identities of ASVs found within the cultures and the environmental sample were

465 assigned by QIIME2. For each culture, ASVs represented by fewer than 20 reads were discarded

466 from the data set in order to account for potential sequencing error. Subsequently, the proportion

467 of each ASV in an individual culture was calculated using the read count for that ASV divided

468 by the total reads from the culture, post-curation. Cultures were functionally divided into three

469 separate categories: "monocultures", "mixed cultures", and cultures with no discernable,

470 dominant member. All cultures that consisted of $\geq 90 \%$ of reads from a single ASV and contained

471 no other ASVs that were $\geq 5 \%$ of reads were categorized as "monocultures", and that ASV was

472 assigned a unique isolate identifier in the Hawai' $i$ Institute of Marine Biology Culture Collection

473 (prefix "HIMB", followed by unique number). Cultures were defined as "mixed" if they (i)

474 contained an ASV that accounted for $<90 \%$ but $\geq 50 \%$ of the total reads for that particular

475 culture. This ASV, as well as any other ASV within the mixed culture that contained $>5 \%$ of the

476 total reads, were assigned unique HIMB identification numbers. (ii) The culture consisted of

$477 \geq 90 \%$ of reads from a single ASV and an additional ASV that was $\geq 5 \%$ of reads. Each of these

478 were also assigned unique HIMB identification numbers. The final category consisted of culture

479 wells that contained no ASVs accounting for $\geq 50 \%$ of the total reads; these were not considered

480 further in the context of this study.

482 Analysis of environmental sample

483 All ASVs represented by $<20$ reads in the environmental sample were removed in order

484 to account for sequencing error and artifacts. All ASVs that were taxonomically identified as 
485 "chloroplast" at the bacterial order-level in the Silva taxonomy were also removed from the data

486 set. The relative abundance of each remaining ASV was calculated as the read count of the

487 individual ASV divided by the total number of reads in the environmental sample, post-curation.

488 Unique identifiers were assigned to all ASVs that remained in the dataset post-curation.

490 Culturability statistics

$491 \quad$ Fundamental culturability statistics were derived as outlined previously (16). Briefly,

492 percent viability (culturability), $V$, is defined as the ratio of the number of viable cells to the total

493 number of cells initially present. It was calculated using the formula:

$$
V=-\ln (1-p) / X
$$

495 Where $p$ is the proportion of wells that scored positive for growth and $X$ is the number of cells 496 used for the initial inoculation. To obtain 95\% confidence intervals, the exact upper and lower $49795 \%$ confidence limits for $p$ were calculated and inserted back into the original viability equation 498 in place of $p$. The result is the exact upper and lower 95\% confidence limits for percent

499 culturability. For this experiment, $p$ is defined as the number of cultures that were determined to

500 be either monocultures or mixed cultures as described above. Two separate culturability statistics

501 were calculated: one including mono- and mixed cultures, and one only including monocultures.

\section{Phylogenetic analyses}

Amplicon sequences corresponding to all ASVs were imported into the ARB software 505 package (62) and aligned to a curated database of marine bacterial 16S rRNA gene sequences.

506 Phylogenetic analyses were performed using the RAxML maximum likelihood method with the

507 GTR model of nucleotide substitution under the gamma and invariable- models of rate 
bioRxiv preprint doi: https://doi.org/10.1101/2020.09.22.309336; this version posted September 23, 2020. The copyright holder for this preprint (which was not certified by peer review) is the author/funder, who has granted bioRxiv a license to display the preprint in perpetuity. It is made available under aCC-BY-NC-ND 4.0 International license.

508 heterogeneity (63). The heat map of ASV relative abundance was constructed in R v.3.5 (58)

509 using the ggplot2 package (60).

510

\section{Data availability}

512 Amplicon sequencing data are available in the Sequencing Read Archive (SRA) under bioproject

513 number $\operatorname{xxxxxxxx.}$

514

515 


\section{Acknowledgements}

517 We thank the Center for Genomic Research and Biocomputing at Oregon State University for

518 DNA sequencing, and Dr. Catherine M. Foley for her generous help with the creation of the

519 maps used in Figure 1. This research was supported by funding from the National Science

520 Foundation (grant OCE-1538628 to MSR), the Hawai'i Institute of Marine Biology (Lord

521 Scholarship fund and graduate research assistantship to EM), and the University of Hawai' $\mathrm{i}$

522 Marine Biology Graduate Program (to EM). This is SOEST contribution xxx and HIMB

523 contribution $\mathrm{xxx}$. 


\section{References}

527 1. Baker BJ, Dick GJ. 2013. Omic approaches in microbial ecology: charting the unknown.

$528 \quad$ Microbe 8:353-360.

529 2. Solden L, Lloyd KG, Wrighton K. 2016. The bright side of microbial dark matter: Lessons

530 learned from the uncultivated majority. Curr Opin Microbiol 31:217-226.

531 3. Tsementzi D, Wu J, Deutsch S, Nath S, Rodriguez-R LM, Burns AS, Ranjan P, Sarode N,

532 Malmstrom RR, Padilla CC, Stone BK, Bristow LA, Larsen M, Glass JB, Thamdrup B,

533 Woyke T, Konstantinidis KT, Stewart FJ. 2016. SAR11 bacteria linked to ocean anoxia

534 and nitrogen loss. Nature 536:179-183.

535 4. Durham BP, Boysen AK, Carlson LT, Groussman RD, Heal KR, Cain KR, Morales RL,

536 Coesel SN, Morris RM, Ingalls AE, Armbrust EV. 2019. Sulfonate-based networks

537 between eukaryotic phytoplankton and heterotrophic bacteria in the surface ocean. Nat

$538 \quad$ Microbiol 4:1706-1715.

539 5. Giovannoni SJ, Stingl U. 2007. The importance of culturing bacterioplankton in the $540 \quad$ “omics” age. Nat Rev Microbiol 5:820-826.

541 6. Rappé MS. 2013. Stabilizing the foundation of the house that 'omics builds: The evolving

542 value of cultured isolates to marine microbiology. Curr Opin Microbiol 16:618-624.

543 7. Carini P. 2019. A "cultural" renaissance: genomics breathes new life into an old craft.

$544 \quad$ mSystems 4:e00092-19.

545 8. Thrash JC. 2019. Culturing the uncultured: risk versus reward. mSystems 4:e00130-19.

546 9. Gifford SM, Sharma S, Booth M, Moran MA. 2013. Expression patterns reveal niche 547 diversification in a marine microbial assemblage. ISME J 7:281-298.

548 10. Yooseph S, Nealson KH, Rusch DB, McCrow JP, Dupont CL, Kim M, Johnson J, 
Montgomery R, Ferriera S, Beeson K, Williamson SJ, Tovchigrechko A, Allen AE,

Zeigler LA, Sutton G, Eisenstadt E, Rogers YH, Friedman R, Frazier M, Venter JC. 2010.

11. Lloyd KG, Steen AD, Ladau J, Yin J, Crosby L. 2018. Phylogenetically novel uncultured microbial cells dominate Earth microbiomes. mSystems 3:e00055-18.

12. Zengler K, Toledo G, Rappé M, Elkins J, Mathur EJ, Short JM, Keller M. 2002.

557 13. Kaeberlein T, Lewis K, Epstein SS. 2002. Isolating "uncultivable” microorganisms in pure culture in a simulated natural environment. Science 296:1127-1129.

559 14. Aoi Y, Kinoshita T, Hata T, Ohta H, Obokata H, Tsuneda S. 2009. Hollow-fiber membrane chamber as a device for in situ environmental cultivation. Appl Environ Microbiol 75:3826-3833.

562 15. Vartoukian SR, Palmer RM, Wade WG. 2010. Strategies for culture of 'unculturable' bacteria. FEMS Microbiol Lett 309:1-7.

564 16. Button DK, Schut F, Quang P, Martin R, Robertson BR. 1993. Viability and isolation of 565 marine bacteria by dilution culture: theory, procedures, and initial results. Appl Environ $566 \quad$ Microbiol 59:881-891.

567 17. Schut F, de Vries EJ, Gottschal JC, Robertson BR, Harder W, Prins RA, Button DK. 1993. Isolation of typical marine bacteria by dilution culture: growth, maintenance, and characteristics of isolates under laboratory conditions. Appl Environ Microbiol 59:21502160.

571 18. Schut F, Gottschal JC, Prins RA. 1997. Isolation and characterisation of the marine 
ultramicrobacterium Sphingomonas sp. strain RB2256. FEMS Microbiol Rev 20:363-369.

573 19. Connon SA, Giovannoni SJ. 2002. High-throughput methods for culturing microorganisms in very-low-nutrient media yield diverse new marine isolates. Appl Environ Microbiol 68:3878-3885.

576 20. Rappé MS, Connon SA, Vergin KL, Giovannoni SJ. 2002. Cultivation of the ubiquitous SAR11 marine bacterioplankton clade. Nature 418:630-633.

578 21. Morris RM, Rappé MS, Connon SA, Vergin KL, Siebold WA, Carlson CA, Giovannoni SJ. 2002. SAR11 clade dominates ocean surface bacterioplankton communities. Nature

581 22. Giovannoni SJ, Britschgi TB, Moyer CL, Field KG. 1990. Genetic diversity in Sargasso Sea bacterioplankton. Nature 345:60-63.

583 23. Stingl U, Tripp HJ, Giovannoni SJ. 2007. Improvements of high-throughput culturing yielded novel SAR11 strains and other abundant marine bacteria from the Oregon coast and the Bermuda Atlantic Time Series study site. ISME J 1:361-371.

24. Song J, Oh HM, Cho JC. 2009. Improved culturability of SAR11 strains in dilution-toextinction culturing from the East Sea, West Pacific Ocean. FEMS Microbiol Lett 295:141-147.

589 25. Oh HM, Kang I, Lee K, Jang Y, Lim S Il, Cho JC. 2011. Complete genome sequence of strain IMCC9063, belonging to SAR11 subgroup 3, isolated from the Arctic Ocean. J Bacteriol 193:3379-3380.

26. Grote J, Cameron Thrash J, Huggett MJ, Landry ZC, Carini P, Giovannoni SJ, Rappé MS. 2012. Streamlining and core genome conservation among highly divergent members of the SAR11 clade. MBio 3: e00252-12. 
27. Henson MW, Celeste Lanclos V, Pitre DM, Lee Weckhorst J, Cheng C, Temperton B, Cameron Thrash J. 2020. Expanding the diversity of bacterioplankton isolates and modeling isolation efficacy with large scale dilution-to-extinction cultivation. Appl Environ Microbiol 86:1104-1123.

28. Jimenez-Infante F, Ngugi DK, Vinu M, Blom J, Alam I, Bajic VB, Stingl U. 2017. Genomic characterization of two novel SAR11 isolates from the Red Sea, including the first strain of the SAR11 Ib clade. FEMS Microbiol Ecol 93.

29. Huggett MJ, Hayakawa DH, Rappé MS. 2012. Genome sequence of strain HIMB624, a cultured representative from the OM43 clade of marine Betaproteobacteria. Stand Genomic Sci 6:11-20.

30. Grote J, Bayindirli C, Bergauer K, de Moraes PC, Chen H, D’Ambrosio L, Edwards B, Fernández-Gómez B, Hamisi M, Logares R, Nguyen D, Rii YM, Saeck E, Schutte C,

611 31. Cho JC, Giovannoni SJ. 2004. Cultivation and growth characteristics of a diverse group of oligotrophic marine Gammaproteobacteria. Appl Environ Microbiol 70:432-440.

613 32. Marshall KT, Morris RM. 2013. Isolation of an aerobic sulfur oxidizer from the SUP05/Arctic96BD-19 clade. ISME J 7:452-455. of the extreme oligotroph “Candidatus Pelagibacter ubique” HTCC1062 on a defined medium. ISME J 7:592-602. 
618 34. White AE, Giovannoni SJ, Zhao Y, Vergin K, Carlson CA. 2019. Elemental content and stoichiometry of SAR11 chemoheterotrophic marine bacteria. Limnol Oceanogr Lett $4: 44-51$.

621 35. Huggett MJ, Rappé MS. 2012. Genome sequence of strain HIMB55, a novel marine gammaproteobacterium of the OM60/NOR5 clade. J Bacteriol 194:2393-2394.

623 36. Durham BP, Grote J, Whittaker KA, Bender SJ, Luo H, Grim SL, Brown JM, Casey JR, Dron A, Florez-Leiva L, Krupke A, Luria CM, Mine AH, Nigro OD, Pather S, Talarmin A, Wear EK, Weber TS, Wilson JM, Church MJ, DeLong EF, Karl DM, Steward GF, Eppley JM, Kyrpides NC, Schuster S, Rappé MS. 2014. Draft genome sequence of marine alphaproteobacterial strain HIMB11, the first cultivated representative of a unique lineage within the Roseobacter clade possessing an unusually small genome. Stand Genomic Sci

37. Haro-Moreno JM, Rodriguez-Valera F, Rosselli R, Martinez-Hernandez F, Roda-Garcia JJ, Gomez ML, Fornas O, Martinez-Garcia M, López-Pérez M. 2020. Ecogenomics of the SAR11 clade. Environ Microbiol 22:1748-1763.

38. Delmont TO, Kiefl E, Kilinc O, Esen OC, Uysal I, Rappé MS, Giovannoni S, Eren AM. 2019. Single-amino acid variants reveal evolutionary processes that shape the biogeography of a global SAR11 subclade. Elife 8:e46497.

39. Steindler L, Schwalbach MS, Smith DP, Chan F, Giovannoni SJ. 2011. Energy starved candidatus Pelagibacter ubique substitutes light-mediated ATP production for endogenous carbon respiration. PLoS One 6:e19725.

40. Carini P, Van Mooy BAS, Thrash JC, White A, Zhao Y, Campbell EO, Fredricks HF, 
Natl Acad Sci U S A 112:7767-7772.

642 41. Carlson CA, Morris R, Parsons R, Treusch AH, Giovannoni SJ, Vergin K. 2009. Seasonal dynamics of SAR11 populations in the euphotic and mesopelagic zones of the

42. Morris RM, Frazar CD, Carlson CA. 2012. Basin-scale patterns in the abundance of SAR11 subclades, marine Actinobacteria (OM1), members of the Roseobacter clade and OCS116 in the South Atlantic. Environ Microbiol 14:1133-1144.

43. Ngugi DK, Antunes A, Brune A, Stingl U. 2012. Biogeography of pelagic bacterioplankton across an antagonistic temperature-salinity gradient in the Red Sea. Mol Ecol 21:388-405.

44. Giovannoni SJ, Hayakawa DH, Tripp HJ, Stingl U, Givan SA, Cho JC, Oh HM, Kitner JB, Vergin KL, Rappé MS. 2008. The small genome of an abundant coastal ocean methylotroph. Environ Microbiol 10:1771-1782.

45. Paerl RW, Sundh J, Tan D, Svenningsen SL, Hylander S, Pinhassi J, Andersson AF,

Riemann L. 2018. Prevalent reliance of bacterioplankton on exogenous vitamin B1 and

46. Garcia SL. 2016. Mixed cultures as model communities: hunting for ubiquitous microorganisms, their partners, and interactions. Aquat Microb Ecol 77:79-85.

47. Garcia SL, Buck M, Hamilton JJ, Wurzbacher C, Grossart H-P, McMahon KD, Eiler A. free-living freshwater bacteria. mSphere 3:e00202-18. 
744.

665

666

667

668

669

670

671

672

673
49. Suzuki MT, Béjà O, Taylor LT, DeLong EF. 2001. Phylogenetic analysis of ribosomal RNA operons from uncultivated coastal marine bacterioplankton. Environ Microbiol $3: 323-331$.

50. Yeo SK, Huggett MJ, Eiler A, Rappé MS. 2013. Coastal bacterioplankton community dynamics in response to a natural disturbance. PLoS One 8:e56207.

51. Grant SR, Church MJ, Ferrón S, Laws EA, Rappé MS. 2019. Elemental composition, phosphorous uptake, and characteristics of growth of a SAR11 strain in batch and continuous culture. mSystems 4:e00218-18.

52. Parada AE, Needham DM, Fuhrman JA. 2016. Every base matters: Assessing small subunit rRNA primers for marine microbiomes with mock communities, time series and global field samples. Environ Microbiol 18:1403-1414.

53. Vergin KL, Urbach E, Stein JL, DeLong EF, Lanoil BD, Giovannoni SJ. 1998. Screening of a fosmid library of marine environmental genomic DNA fragments reveals four clones related to members of the order Planctomycetales. Appl Environ Microbiol 64:3075-3078.

54. Lane DJ. 1991. 16S/23S rRNA sequencing, p. 115-175. In Stackebrandt, E, Goodfellow, M (eds.), Nucleic Acid Techniques in Bacterial Systematics. John Wiley \& Sons, New York.

55. Bolyen E, Rideout JR, Dillon MR, et al. 2019. Reproducible, interactive, scalable and extensible microbiome data science using QIIME 2. Nat Biotechnol 37:852-857.

56. Callahan BJ, McMurdie PJ, Rosen MJ, Han AW, Johnson AJA, Holmes SP. 2016. DADA2: High-resolution sample inference from Illumina amplicon data. Nat Methods 13:581-583. 
687 57. Quast C, Pruesse E, Yilmaz P, Gerken J, Schweer T, Yarza P, Peplies J, Glöckner FO. 2013. The SILVA ribosomal RNA gene database project: improved data processing and web-based tools. Nucleic Acids Res 41:D590-D596.

690 58. R Core Team. 2013. R: A language and environment for statistical computing. R Foundation for Statistical Computing, Vienna, Austria.

692 59. McMurdie PJ, Holmes SP. 2013. phyloseq: An R package for reproducible interactive analysis and graphics of microbiome census data. PLoS One 8:e61217.

694 60. Wickham H. 2009. ggplot2: elegant graphics for data analysis. Springer-Verlag, New York.

696 61. Hulsen T, de Vlieg J, Alkema W. 2008. BioVenn - A web application for the comparison and visualization of biological lists using area-proportional Venn diagrams. BMC Genomics 9:488.

699 62. Ludwig W, Strunk O, Westram R, Richter L, Meier H, Buchner A, Lai T, Steppi S, Jobb G, Förster W, Brettske I, Gerber S, Ginhart AW, Gross O, Grumann S, Hermann S, Jost software environment for sequence data. Nucleic Acids Res 32:1363-1371. 


\section{Figure Legends}

708 Figure 1. Map indicating the location of stations STO1 (red triangle) and SR4 (black circle) in

709 the vicinity of Kāne'ohe Bay on the island of O'ahu, Hawai'i, where seawater used as inoculum

710 (STO1) and media preparation (SR4) were collected.

712 Figure 2. Outline of experiments performed in this study.

714 Figure 3. Phylogenetic analysis of the SAR11 clade illustrating relationships among 16S rRNA

715 gene ASVs recovered from isolates and the source seawater used as inoculum in this study. The

716 scale bar corresponds to 0.1 substitutions per nucleotide position. A variety of

717 Alphaproteobacteria were used as an outgroup. Previously cultured isolates ("str.") and select

718 environmental gene clones were included as references. Boxes labeled "Env" indicate the

719 relative environmental abundance of each ASV (blue gradient), while orange (“2017”) and green

720 (“2018”) boxes indicate the presence of an ASV in the fresh (HTC2017) and cryopreserved

721 (HTC2018) seawater cultivation experiments respectively. Boxes containing a slash in the "Env"

722 column indicate ASVs was found in a culture but were not detected in the environmental sample.

724 Figure 4. Venn diagrams comparing (A) SAR11 ASVs identified within the environmental

725 seawater sample used as inoculum, isolates from the fresh seawater cultivation experiment

726 (HTC2017), and isolates from the cryopreserved seawater cultivation experiment (HTC2018).

727 (B) Same as (A), except limited to SAR11 subclade Ia ASVs. 
729 Figure 5. Phylogenetic analysis of select lineages of Alpha- and Gammaproteobacteria

730 illustrating relationships among 16S rRNA gene ASVs recovered from isolates and the source

731 seawater used as inoculum in this study. The scale bar corresponds to 0.1 substitutions per

732 nucleotide position. A variety of Betaproteobacteria were used as an outgroup. Previously

733 cultured isolates (“str.") and select environmental gene clones were included as references.

734 Boxes labeled "Env" indicate the relative environmental abundance of each ASV (blue gradient),

735 while orange ("2017”) and green (“2018”) boxes indicate the presence of an ASV in the fresh

736 (HTC2017) and cryopreserved (HTC2018) seawater cultivation experiments respectively. Boxes

737 containing a slash in the "Env" column indicate ASVs was found in a culture but were not

738 detected in the environmental sample.

740 Figure S1. Relative abundance (bubble size) of ASVs identified in mixed cultures from

741 cultivation experiments using fresh seawater (HTC2017, 5-cell inoculum) and cryopreserved

742 seawater (HTC2018 5-cell and 105-cell inocula). Bar charts represent the number of

743 monocultures matching these ASVs cultivated in the two experiments. 


\section{TABLES}

746 Table 1. Culturability statistics from fresh (HTC2017) and cryopreserved (HTC2018) seawater

747 cultivation experiments.

748

749 Table 2. Summary of isolates from fresh (HTC2017) and cryopreserved (HTC2018) seawater

750 cultivation experiments, including the relative abundance of each taxonomic group in the

751 environmental sample based on SSU rRNA gene sequencing.

752

753 Table S1. Summary of ASVs, mixed cultures, and isolates recovered in this study. 
Table 1. Culturability statistics from fresh (HTC2017) and cryopreserved (HTC2018) seawater cultivation experiments.

\begin{tabular}{cccccccc}
\hline $\begin{array}{c}\text { Inoculum } \\
\text { source }\end{array}$ & $\begin{array}{c}\text { Inoculum size } \\
(\text { cells })^{\mathrm{a}}\end{array}$ & $\begin{array}{c}\text { Inoculated } \\
\text { cultures }\end{array}$ & $\begin{array}{c}\text { Mono- \& mixed cultures } \\
\text { Positive }^{\text {cultures }}{ }^{\mathrm{b}}\end{array}$ & $\begin{array}{c}\text { Monocultures only } \\
(\%)^{\mathrm{c}}\end{array}$ & $\begin{array}{c}\text { Positive } \\
\text { cultures }^{\mathrm{b}}\end{array}$ & $\begin{array}{c}\text { Culturability } \\
(\%)^{\mathrm{c}}\end{array}$ \\
\hline $\begin{array}{c}\text { HTC2017 } \\
\text { fresh seawater }\end{array}$ & 5 & 576 & 83 & $3.1(2.5,3.9)$ & 54 & $2.0(1.5,2.6)$ \\
$\begin{array}{c}\text { HTC2018 } \\
\text { cryopreserved } \\
\text { seawater }\end{array}$ & 5 & 480 & 50 & $2.2(1.6,2.9)$ & 39 & $1.7(1.2,2.3)$ \\
\hline
\end{tabular}

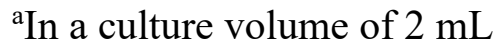

${ }^{\mathrm{b}}$ Calculated as the number of inoculated cultures that resulted in growth of either a monoculture or mixed culture (see Methods for definition). The constituent members of all mixed cultures are listed in Table S1.

${ }^{\mathrm{c}}$ Ninety-five percent confidence intervals are shown in parentheses 
Table 2. Summary of isolates from fresh (HTC2017) and cryopreserved (HTC2018) seawater cultivation experiments, including the relative abundance of each taxonomic group in the environmental sample based on SSU rRNA gene sequencing.

\begin{tabular}{|c|c|c|c|c|c|c|}
\hline \multirow[b]{2}{*}{ Taxonomy $^{\mathrm{a}}$} & \multicolumn{2}{|c|}{ HTC2017 } & \multicolumn{2}{|c|}{ HTC2018 } & \multicolumn{2}{|c|}{ Seawater ${ }^{b}$} \\
\hline & ASVs & Strains & ASVs & Strains & ASVs & $\begin{array}{l}\text { Abundance } \\
\text { (rel. \%) }\end{array}$ \\
\hline $\begin{array}{l}\text { Alphaproteobacteria, SAR11 } \\
\text { subclade Ia }\end{array}$ & 9 & 47 & 9 & 68 & 10 & 10.23 \\
\hline $\begin{array}{l}\text { Alphaproteobacteria, SAR11 } \\
\text { subclade Ib }\end{array}$ & 2 & 4 & 2 & 3 & 14 & 7.74 \\
\hline $\begin{array}{l}\text { Alphaproteobacteria, SAR11 } \\
\text { subclade IIIa }\end{array}$ & 0 & 0 & 1 & 2 & 4 & 0.42 \\
\hline $\begin{array}{l}\text { Alphaproteobacteria, SAR11 } \\
\text { subclade Va }\end{array}$ & 0 & 0 & 1 & 1 & 2 & 2.13 \\
\hline $\begin{array}{l}\text { Alphaproteobacteria, } \\
\text { Rhodobacteraceae }\end{array}$ & 4 & 14 & 5 & 5 & 12 & 5.81 \\
\hline $\begin{array}{l}\text { Alphaproteobacteria, SAR116 } \\
\text { clade }\end{array}$ & 1 & 1 & 0 & 0 & 23 & 5.41 \\
\hline Alphaproteobacteria, PS1 clade & 1 & 3 & 3 & 4 & 3 & 0.42 \\
\hline $\begin{array}{l}\text { Gammaproteobacteria, } \\
\text { Halieaceae, OM60(NOR5) clade }\end{array}$ & 4 & 24 & 5 & 21 & 5 & 1.91 \\
\hline $\begin{array}{l}\text { Gammaproteobacteria, KI89A } \\
\text { clade }\end{array}$ & 1 & 1 & 0 & 0 & 4 & 0.60 \\
\hline $\begin{array}{l}\text { Betaproteobacteriales, } \\
\text { Burkholderia-Caballeronia- } \\
\text { Paraburkholderia }\end{array}$ & 1 & 4 & 1 & 1 & 2 & 0.11 \\
\hline $\begin{array}{l}\text { Betaproteobacteriales, } \\
\text { Methylophilaceae, OM43 clade }\end{array}$ & 2 & 5 & 0 & 0 & 1 & 0.04 \\
\hline $\begin{array}{l}\text { Gammaproteobacteria, } \\
\text { Pseudomonadaceae, } \\
\text { Pseudomonas }\end{array}$ & 1 & 2 & 0 & 0 & 0 & 0 \\
\hline $\begin{array}{l}\text { Gammaproteobacteria, } \\
\text { Rhodanobacteraceae }\end{array}$ & 1 & 2 & 0 & 0 & 0 & 0 \\
\hline $\begin{array}{l}\text { Actinobacteria, } \\
\text { Corynebacteriaceae }\end{array}$ & 0 & 0 & 1 & 1 & 0 & 0 \\
\hline $\begin{array}{l}\text { Actinobacteria, } \\
\text { Geodermatophilaceae }\end{array}$ & 0 & 0 & 1 & 1 & 0 & 0 \\
\hline $\begin{array}{l}\text { Bacteroidetes, Chitinophagaceae, } \\
\text { Sediminibacterium }\end{array}$ & 0 & 0 & 1 & 1 & 0 & 0 \\
\hline Fungi & 1 & 1 & 1 & 2 & 0 & 0 \\
\hline
\end{tabular}

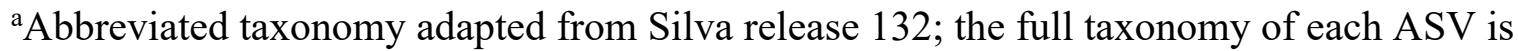
available in Table S1.

${ }^{b}$ Environmental relative abundance was calculated using read counts of all environmental ASVs detected in the seawater sample from within each taxonomic grouping, after curation to remove ASVs originating from chloroplasts. 
bioRxiv preprint doi: https://doi.org/10.1101/2020.09.22.309336; this version posted September 23, 2020. The copyright holder for this preprint (which was not certified by peer review) is the author/funder, who has granted bioRxiv a license to display the preprint in perpetuity. It is made available under aCC-BY-NC-ND 4.0 International license.

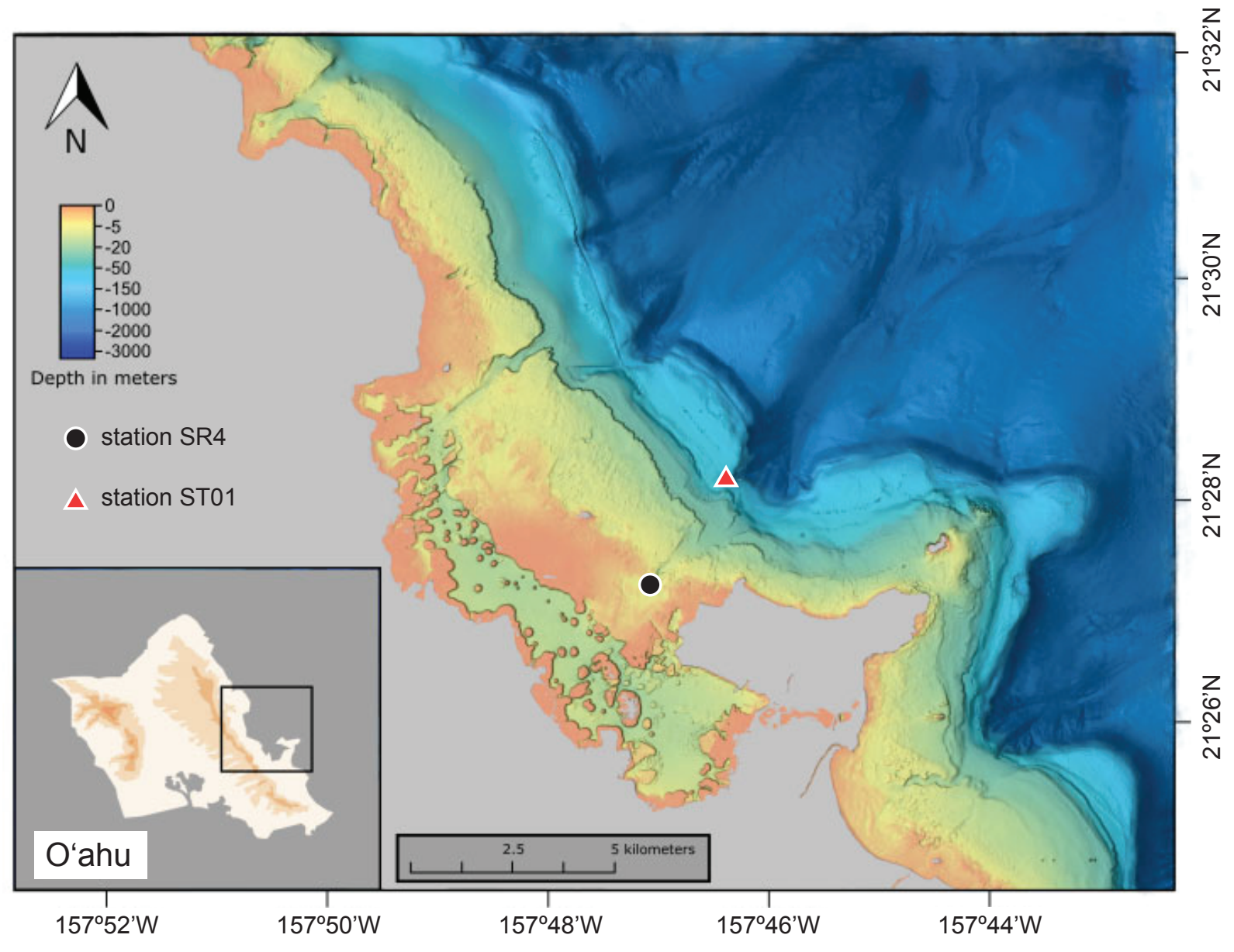


bioRxiv preprint doi: https://doi.org/10.1101/2020.09.22.309336; this version posted September 23, 2020. The copyright holder for this preprint (which was not certified by peer review) is the author/funder, who has granted bioRxiv a license to display the preprint in perpetuity. It is made available under aCC-BY-NC-ND 4.0 International license.

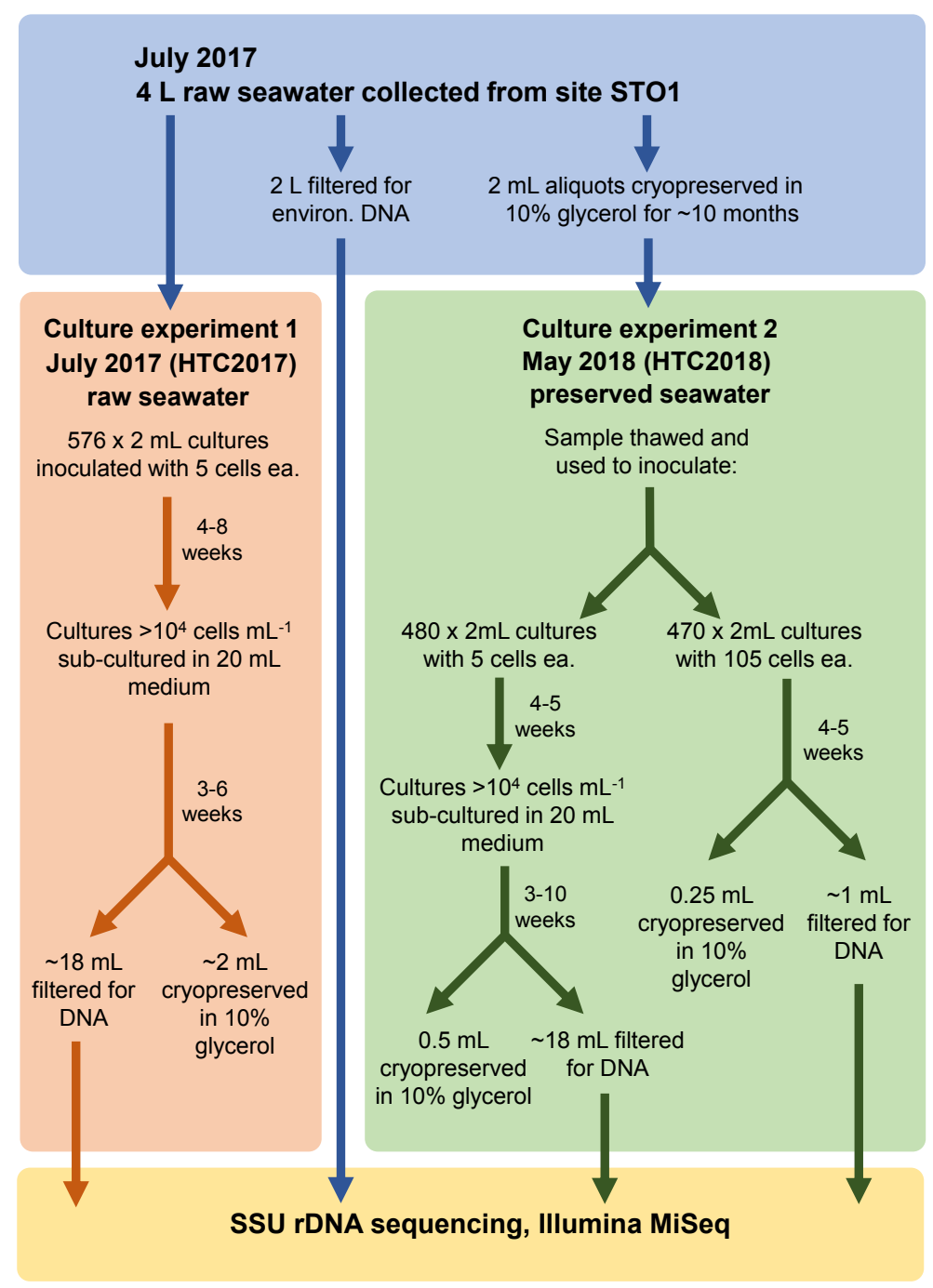


bioRxiv preprint doi: https://doi.org/10.1101/2020 09 22 309336. this version posted September 23,2020 . The copyright holder for this preprint (which was not certified by peer review) is the author/funder, who has granted bioRxiv a license to display the preprint in perpetuity. It is made available under aCC-BY-NC-ND 4.0 International license.

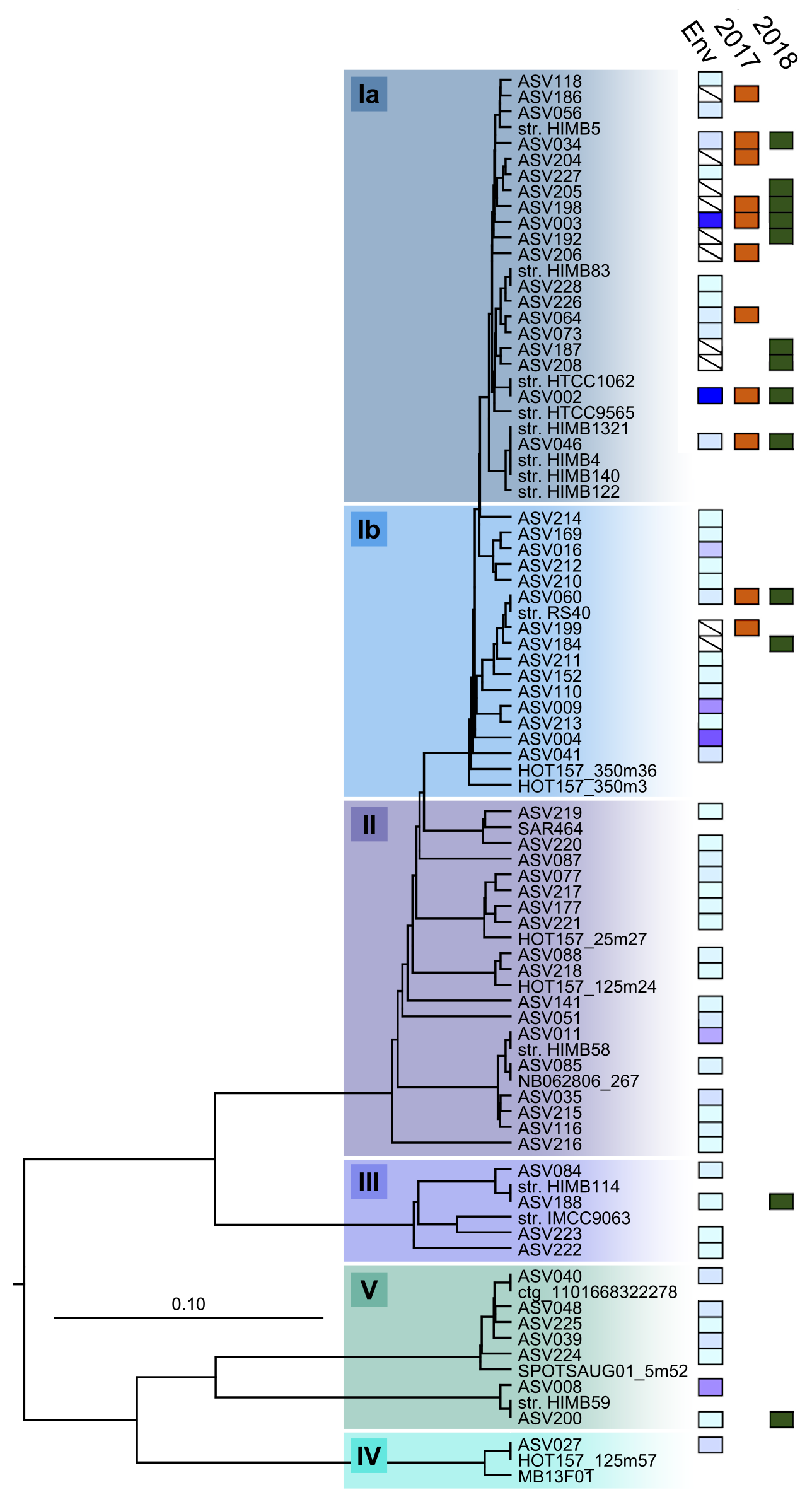

Env. rel. abundance

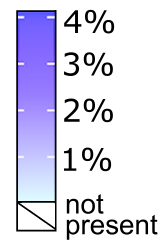


bioRxiv preprint doi: https://doi.org/10.1101/2020.09.22.309336; this version posted September 23, 2020. The copyright holder for this preprint (which was not certified by peer review) is the author/funder, who has granted bioRxiv a license to display the preprint in perpetuity. It is made available under aCC-BY-NC-ND 4.0 International license.

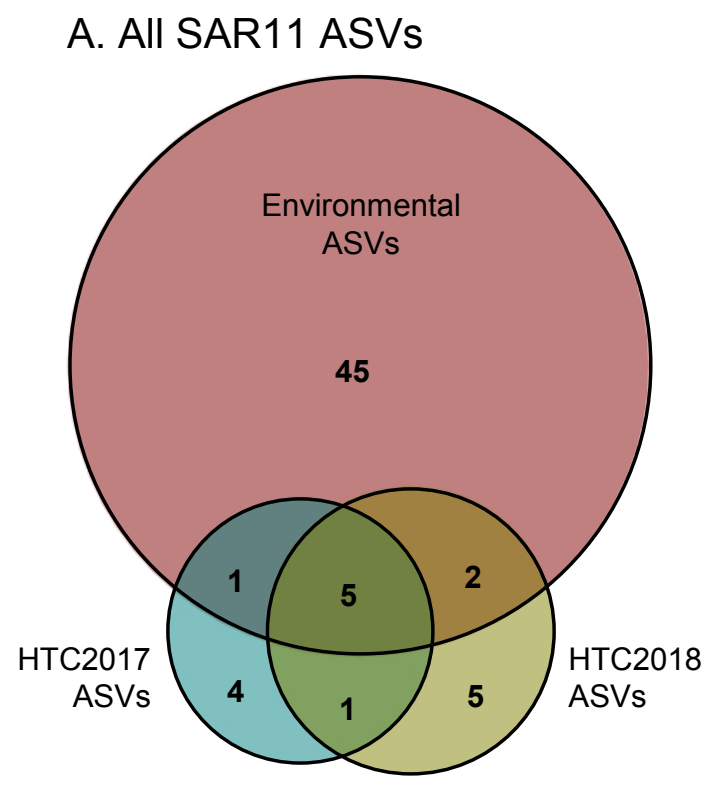

\section{B. SAR11 subclade la ASVs}

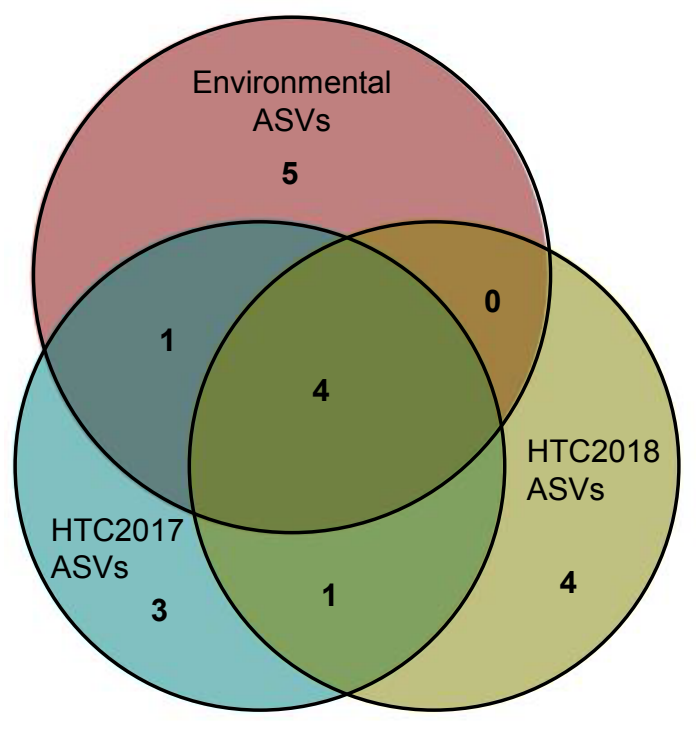


bioRxiv preprint doi: https://doi.org/10.1101/2020.09.22.309336; this version posted September 23, 2020. The copyright holder for this preprint (which was not certified by peer review) is the author/funder, who has granted bioRxiv a license to display the preprint in perpetuity. It is made available under aCC-BY-NC-ND 4.0 International license.

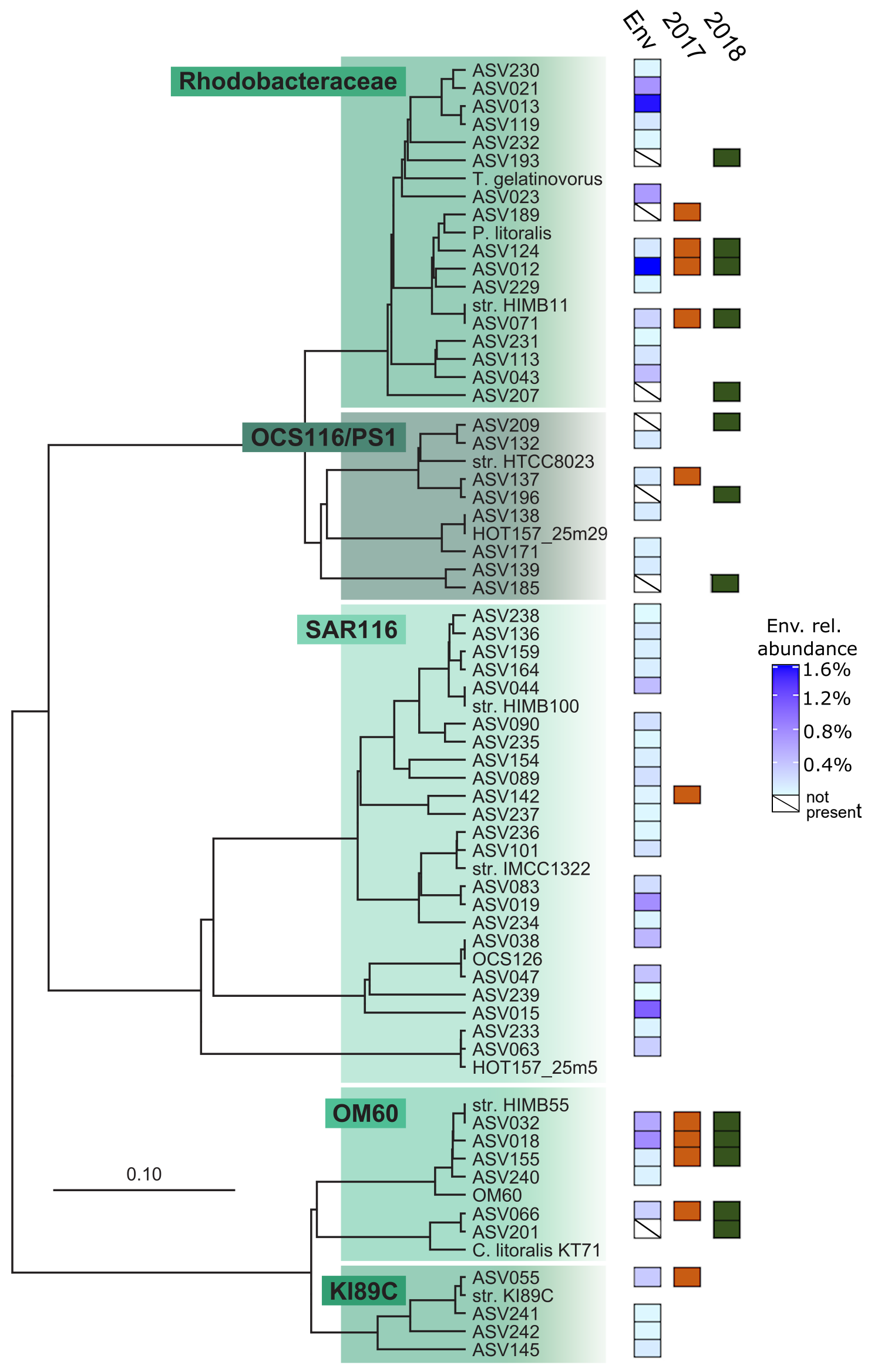


bioRxiv preprint doi: https://doi.org/10.1101/2020.09.22.309336; this version posted September 23, 2020. The copyright holder for this preprint (which was not certified by peer review) is the author/funder, who has granted bioRxiv a license to display the preprint in perpetuity. It is made available under aCC-BY-NC-ND 4.0 International license.

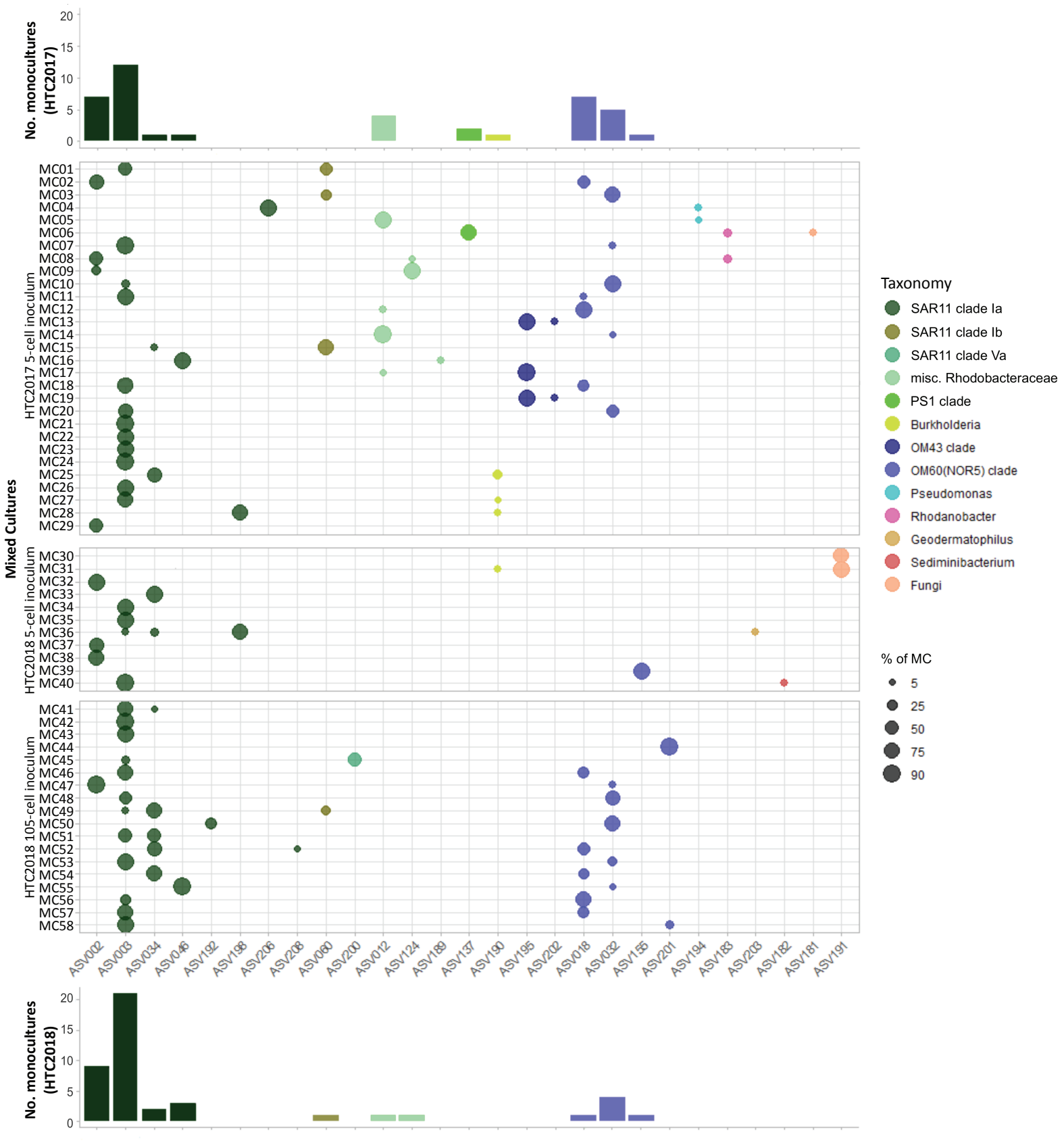

